\title{
Impact of cytochrome P450 2C19 polymorphisms on the clinical efficacy and safety of voriconazole: an update systematic review and meta-analysis
}

\author{
Ying Zhang ${ }^{1}$, Xu Hao ${ }^{1}$, Kelu Hou ${ }^{1}$, Lei Hu${ }^{1}$, Jingyuan Shang ${ }^{1}$, Shiyu He ${ }^{1}$, Changqing \\ Yang $^{2}$, Yufei Feng ${ }^{1}$, and Lin Huang ${ }^{1}$ \\ ${ }^{1}$ Peking University People's Hospital \\ ${ }^{2}$ China Pharmaceutical University
}

July 5, 2021

\begin{abstract}
Aims: To assess the impact of cytochrome P450 (CYP) 2C19 polymorphisms on the clinical efficacy and safety of voriconazole. Methods: We systematically searched PubMed, EMBASE, CENTRAL, ClinicalTrials.gov, and three Chinese databases from their inception to March 18, 2021 using a predefined search algorithm to identify relevant studies. Studies that reported voriconazole-treated patients and information on CYP2C19 polymorphisms were included. The efficacy outcome was success rate. The safety outcomes included overall adverse events, hepatotoxicity and neurotoxicity. Results: A total of 20 studies were included. Intermediate metabolizers (IMs) and Poor metabolizers (PMs) were associated with increased success rates compared with normal metabolizers (NMs) (risk ratio (RR): 1.18, 95\% confidence interval (CI): 1.03 1.34, I2=0\%, p=0.02; RR: 1.28, 95\% CI: $\left.1.06^{\sim} 1.54, \mathrm{I} 2=0 \%, \mathrm{p}=0.01\right)$. PMs were at increased risk of overall adverse events in comparison with NMs and IMs (RR: $2.18,95 \%$ CI: $1.35^{\sim} 3.53, \mathrm{I} 2=0 \%, \mathrm{p}=0.001$; RR: $1.80,95 \%$ CI: $1.23^{\sim} 2.64, \mathrm{I} 2=0 \%, \mathrm{p}=0.003$ ). PMs demonstrated a trend towards an increased incidence of hepatotoxicity when compared with NMs (RR: $1.60,95 \% \mathrm{CI}: 0.94 \sim 2.74, \mathrm{I} 2=27 \%$, p=0.08), although there was no statistically significant difference. In addition, there was no significant association between CYP2C19 polymorphisms and neurotoxicity. Conclusions: IMs and PMs were at a significant higher success rate in comparison with NMs. PMs were significantly associated with an increased incidence of all adverse events compared with NMs and IMs. Researches are expected to further confirm these findings. Additionally, the relationship between hepatotoxicity and CYP2C19 polymorphisms deservers clinical attention.
\end{abstract}

Impact of cytochrome $\mathrm{P} 4502 \mathrm{C} 19$ polymorphisms on the clinical efficacy and safety of voriconazole: an updatesystematic review and meta-analysis

Ying Zhang ${ }^{1,2}$, Xu Hao ${ }^{1,2}$, Kelu $\mathrm{Hou}^{1}$, Lei $\mathrm{Hu}^{1}$, Jingyuan Shang ${ }^{1}$, Shiyu $\mathrm{He}^{1}$, Changqing Yang ${ }^{2}$, Lin Huang $^{1, ~ *}$, Yufei Feng ${ }^{1, *}$

${ }^{1}$ Department of Pharmacy, Peking University People's Hospital, Beijing, 100044, China;

${ }^{2}$ School of Basic Medicine and Clinical Pharmacy, China Pharmaceutical University, Nanjing, 211198, China;

* Corresponding authors at: Department of Pharmacy, Peking University People's Hospital, No. 11 Xizhimen South Street, Xicheng District, Beijing 100044, China. Email: huanglin@pkuph.edu.cn; fenyufei@126.com.

\section{Acknowledgements}

This work was supported by the Beijing Municipal Natural Science Foundation (grant number 7192218). The Foundation had no involvement on study design, collection, analysis and interpretation of data, writing of the report and the decision to submit the article for publication. 


\section{Conflict of interest statement}

The authors declare no competing interests.

\section{CRediT authorship contribution statement}

Ying Zhang: Formal analysis, Investigation, Writing-Original draft, Visualization. Xu Hao: WritingReview \& editing, Visualization. Kelu Hou: Methodology. Lei Hu:Software. Shiyu He: Resources, Data curation. Jingyuan Shang: Resources, Date curation. Changqing Yang: Supervision.Lin Huang: Conceptualization, Supervision, Funding acquisition.Yufei Feng: Supervision, Writing- Review \& editing.

Running head: Genetic factors influencing VRC PDs

Keywords: voriconazole, CYP2C19, polymorphisms, efficacy, safety, meta-analysis

Word count: 2807

Table count : 6

Figure count $: 1$

Abstract

Aims:To assess the impact of cytochrome P450 (CYP) 2C19 polymorphisms on the clinical efficacy and safety of voriconazole.

Methods: We systematically searched PubMed, EMBASE, CENTRAL, ClinicalTrials.gov, and three Chinese databases from their inception to March 18, 2021 using a predefined search algorithm to identify relevant studies. Studies that reported voriconazole-treated patients and information on CYP2C19 polymorphisms were included. The efficacy outcome was success rate. The safety outcomes included overall adverse events, hepatotoxicity and neurotoxicity.

Results: A total of 20 studies were included. Intermediate metabolizers (IMs) and Poor metabolizers (PMs) were associated with increased success rates compared with normal metabolizers (NMs) (risk ratio (RR): 1.18, $95 \%$ confidence interval (CI): $1.03^{\sim} 1.34, I^{2}=0 \%, \mathrm{p}=0.02$; RR: $1.28,95 \%$ CI: $1.06^{\sim} 1.54, I^{2}=0 \%, \mathrm{p}=0.01$ ). PMs were at increased risk of overall adverse events in comparison with NMs and IMs (RR: 2.18, 95\%CI: 1.35 $3.53, I^{2}=0 \%, \mathrm{p}=0.001$; RR: $1.80,95 \%$ CI: $\left.1.23^{\sim} 2.64, I^{2}=0 \%, \mathrm{p}=0.003\right)$. PMs demonstrated a trend towards an increased incidence of hepatotoxicity when compared with NMs (RR: 1.60, 95\%CI: 0.94 2.74, $I^{2}=27 \%, \mathrm{p}=0.08$ ), although there was no statistically significant difference. In addition, there was no significant association between CYP2C19 polymorphisms and neurotoxicity.

Conclusions:IMs and PMs were at a significant higher success rate in comparison with NMs. PMs were significantly associated with an increased incidence of all adverse events compared with NMs and IMs. Researches are expected to further confirm these findings. Additionally, the relationship between hepatotoxicity and CYP2C19 polymorphisms deservers clinical attention.

\section{Introduction}

Invasive fungal diseases (IFDs) are associated with a high morbidity and mortality in the immunocompromised patient ${ }^{1,2}$. Voriconazole is recommended as a first-line treatment for invasive aspergillosis also as antifungal prophylaxis in high-risk patients who are undergoing hematopoietic stem cell transplantation or immunocompromised $^{3-6}$. Given the poor prognosis of patients with IFD, failure with voriconazole treatment potentially threatens life. In addition, the management and prevention of IFD requires substantial expenditures and places a heavy burden on the healthcare system ${ }^{7}$. Therefore, it is necessary to ensure efficacy and safety in clinical practice.

A major drawback of using voriconazole is its insufficient antifungal or higher incidence of hepatotoxic or neurotoxic events ${ }^{8,9}$. The main source of variability in response to voriconazole may lie in its pharmacokinetics. Voriconazole presents extensive hepatic metabolism, predominantly by CYP2C19 ${ }^{10}$. The activity of 
CYP2C19 shows large individual differences due to the existence of gene polymorphism ${ }^{11}$. There are five CYP2C19 phenotypes based on genotype that have been proposed for voriconazole by the clinical pharmacogenetics implementation consortium (CPIC) as follows: (1) normal metabolizers (NMs) $\left(* 1 /{ }^{*} 1\right)$ represents up to $50 \%$ of patients, (2) intermediate metabolizers (IMs) $\left({ }^{*} 1 /{ }^{*} 2,{ }^{*} 1 /{ }^{*} 3,{ }^{*} 2 /{ }^{*} 17\right)$ accounts for $\sim 18-45 \%$ of patients, (3) poor metabolizers (PMs) $\left({ }^{*} 2 /{ }^{*} 2,{ }^{*} 3 /{ }^{*} 3,{ }^{*} 2 /{ }^{*} 3\right)$ accounts for ${ }^{2} 2-15 \%$ of patients, (4) rapid metabolizers $(\mathrm{RMs})(* 1 / * 17)$ accounts for $\sim 2-30 \%$ of patients, $(5)$ ultrarapid metabolizers (UMs) $\left(* 17 / *^{*} 17\right)$ accounts for $\sim 2-5 \%$ of patients ${ }^{12}$.

As we know, the trough concentrations are associated with efficacy and toxicity of voriconazole in clinical practice ${ }^{8,9}$. Recently, we have demonstrated quantitative relations between the CYP2C19 polymorphisms and voriconazole trough concentrations ${ }^{13}$. Accordingly, polymorphisms of the CYP2C19 have been associated with antifungal response and are supposed to predict the variability in clinical response to voriconazole ${ }^{14}$. However, published literatures have not consistently shown an association of CYP2C19 polymorphism with clinical response of voriconazole. The quantitative relations between the pairwise comparisons of CYP2C19 phenotypes in clinical outcome of voriconazole have been first summarized in a systematic review and metaanalysis abstracting data form 10 studies published up to January $2016^{15}$. The reported results showed that patients with PM phenotype had a significantly higher success rate compared with NMs, and there was no significant association between CYP2C19 polymorphisms and overall adverse events, hepatotoxicity and neurotoxicity. Notably, over the past five years, more and more studies in different countries investigated the impact of CYP2C19 polymorphisms on the clinical outcome of patients treated with voriconazole.

Therefore, we conducted an updated systematic review and meta-analysis of studies assessing the association between CYP2C19 polymorphisms and clinical outcomes of voriconazole. The aim of this study was to evaluate the nature and magnitude of the relationship of CYP2C19 polymorphisms with the efficacy and safety of voriconazole. Clarifying this relationship could have important clinical implications for future strategies in optimization of voriconazole.

\section{Methods}

Our study adhered to the PRISMA statements for reporting on systematic reviews ${ }^{16}$.

\subsection{Date sources and search strategy}

We searched PubMed, EMBASE, CENTRAL, ClinicalTrials.gov, and three Chinese databases (CBM, CNKI, and WanFang) from their inception to March 18, 2021 without restrictions of language, age, or race. We applied the following search strategy: (CYP2C19 OR polymorphism OR genotype) AND (voriconazole OR Vfend). Furthermore, we searched references of available reviews for potential eligible studies.

\subsection{Study selection}

Two researchers independently screened titles and abstracts generated by search after removing duplicates in EndNote, and then full texts were required to explore eligible studies. Disagreements were resolved by discussion.

Prospective or retrospective studies were included if they were peer reviewed original reports or original date can be fully accessed. We considered reports that evaluated the association of genetic variants of CYP2C19 with the occurrence of efficacy and safety in patients who were taken with voriconazole. We excluded studies not reporting outcomes separately based on CYP2C19 genotypes or phenotypes.

\subsection{Outcome measures}

We assessed outcome measures based on the following predefined definitions: (1) given the definition of treatment/prophylaxis success inconsistent among the included studies, we used the criteria from each study, (2) overall adverse events were defined as all adverse events regardless of their causal relationship with voriconazole, (3) hepatotoxicity was defined as abnormal liver function after voriconazole initiation, (4) neurotoxicity included headache, vertigo, encephalopathy, hallucinations, confusion, or seizures. 


\subsection{Quality assessment}

The quality of the included studies was assessed using the STRAGE recommendations for reports on genetic association studies ${ }^{17}$. The quality evaluation items were: (1) clear statement of objectives and hypothesis, (2) clear eligibility criteria for study participants, (3) clear definition of all variables, (4) clear definition of the outcome, (5) credible genetic testing method, (6) replicability of statistical method, (7) assessment of Hardy-Weinberg equilibrium (HWE), (8) sufficient descriptive demographic data, (9) clear report of dropout and reasons, (10) statement of outcome data. Each item was recorded as "+" or "-", depending on whether it was described in the text.

\subsection{Data extraction}

Using a standardized form, two authors reviewed and recorded independently the author's last name and year of publication, patients' demographic characteristics (sample size, age, sex), study design, region and ethnicity, the purpose of voriconazole (treatment or prophylaxis), administration of voriconazole, outcome measures (type, number of events and total sample size according to phenotypes), method of genotype measured, CYP2C19 phenotypes. Give the similar activity and the limited sample size of RMs and UMs, we combined them into one group as UMs. Missing date for two studies ${ }^{18,19}$ were extracted from a previous meta-analysis ${ }^{15}$.

\subsection{Statistical analysis}

We calculated risk ratio (RR) and $95 \%$ confidence intervals (CI) for summary effect based on phenotypes. Statistical significance of the summary estimates is determined by Z-tests, and $\mathrm{p}<0.05$ indicated statistical significance. The $I^{2}$ statistic was performed to measure heterogeneity among studies. When $I^{2}[?] 50 \%$, a fixed-effects model was used to derived pooled estimates. Otherwise, a random-effects model was applied. For each outcome, we performed subgroup analysis according to the purpose of voriconazole and ethnicity. To explore the probable sources of heterogeneity among the studies and to assess the robustness of the pooled estimates, we conducted a sensitivity analysis by eliminating each study one by one. Publication bias among studies was assessed using Begg's test and Egger's test. Statistical analysis was performed with Microsoft excel 2019, Review Manger 5.4 and Stata version 16.0.

\section{Result}

\subsection{Literature search}

We identified 3140 records by the literature search (Figure 1), and 1881 remained after removal of duplicates. After screening of titles and abstracts, 36 articles were retrieved for full text assessment. Of these, 16 articles were excluded, mainly because they reported other outcomes. In addition, one study by Fu et al ${ }^{18}$ beyond our search, but it was included in the previous meta-analysis, and thus we included it. Overall, 20 studies were included in the meta-analysis ${ }^{14,18-36}$.

\subsection{Characteristics of included studies}

The detailed characteristics of individual study are presented in Table 1. Years of publication ranged from 2011 to 2020. The participants were all adults. Most of these studies were carried out in Asia (China, Korea). Voriconazole was used for treatment in most studies, and for prophylaxis in three studies ${ }^{23,} 24,26$, as well as for treatment or prophylaxis in three studies ${ }^{18,22,25}$. Most studies followed the standard dosing of $6 \mathrm{mg} / \mathrm{kg}$ (IV)/400mg (Oral) twice daily on day 1 for load and $4 \mathrm{mg} / \mathrm{kg}$ (IV)/200mg (Oral) twice daily for maintenance. There were four studies with genotype-directed dosing. Two of them reported that NMs, IMs and PMs initiated voriconazole at $200 \mathrm{mg}$ twice daily, whereas UMs initiated voriconazole at $300 \mathrm{mg}$ twice daily ${ }^{23,26}$. Two of them reported that IMs and PMs initiated voriconazole at $200 \mathrm{mg}$ twice daily, whereas NMs initiated voriconazole at $400 \mathrm{mg}$ twice daily ${ }^{29,31}$. Thus, we excluded those non-standard dosing groups when conducted analysis. One study was performed on healthy men ${ }^{28}$. Only a few participants were UMs.

\subsection{Quality assessment}


A summary of quality of included studies is presented in Table 2. Except the HWE, all items were described in most of these studies and we graded them as relatively high quality. Two studies ${ }^{18,19}$ did not state outcome data in text but we could acquire them from the previous meta-analysis ${ }^{15}$, which were acceptable for this meta-analysis.

\subsection{Success rate}

Eight studies explored the association of CYP2C19 phenotype with the efficacy outcome of success rate 18, 19, 26, 29, 30, 32, 33, 35 and meta-analysis results were shown in Table 3. Overall, IMs and PMs were at significant higher success rate in comparison with NMs (RR: $1.18,95 \%$ CI: $1.03^{\sim} 1.34, I^{2}=0 \%, \mathrm{P}=0.02$ and RR: $1.28,95 \%$ CI: $1.06^{\sim} 1.54, I^{2}=0 \%, \mathrm{p}=0.01$, respectively) in all studies $18,19,26,30,32,33,35$. There was no significant difference in comparisons between PMs and IMs (RR: 1.04, 95\% CI: $0.92^{\sim} 1.18, I^{2}=0 \%, \mathrm{p}=0.54$ ) $18,19,26,29,30,32,33,35$. We were unable to analyze the difference of success rate between UMs and NMs because there was no eligible study reported the data of UMs. Sensitivity analysis on each comparison showed that results were reliable.

Results of subgroups analysis were shown in Table 3. In the treatment group and the Asians group, results were almost unchanged. There was only one study reported data in the prophylaxis and the Caucasians group, thus we didn't conduct meta-analysis ${ }^{26}$.

\subsection{Overall adverse events}

The most common reported adverse reactions were visual disturbances, fever, nausea, rashes, vomiting, chills, headache, liver function test abnormal, tachycardia and hallucinations.

Thirteen studies analyzed the association of CYP2C19 phenotype with the safety outcome of overall adverse events ${ }^{14,21,25-35}$ and meta-analysis results were shown in Table 4 . In total, PMs were at increased risk of overall adverse events in comparison with NMs (RR:2.18, 95\% CI: $1.35^{\sim} 3.53, I^{2}=37 \%, \mathrm{p}=0.001$ ) $21,25,26,28,30,32-35$ and IMs (RR: $1.80,95 \%$ CI: $\left.1.23^{\sim} 2.64, I^{2}=0 \%, \mathrm{p}=0.003\right){ }^{21}, 25,26,28-35$. There were no significant differences in other comparisons. Sensitivity analysis showed the results did not alter significantly in all comparisons.

Subgroup analysis revealed that the results in groups treatment and Asians were not significantly changed. However, in the subgroup of Caucasians, there were a limited number of studies $\left(2^{\sim} 4\right)$ and no significant differences were found in all comparisons (Table 4). For the subgroup of prophylaxis, there was only one study reported data that five patients experienced a grade 3 adverse events (one IMs, one NMs, and two $\mathrm{UMs})^{26}$.

\subsection{Hepatotoxicity}

Eight studies investigated the association of CYP2C19 phenotype with the safety outcome of hepatotoxicity 20-24, 34-36 and meta-analysis results were shown in Table 5. Our meta-analysis exhibited no statistically significant differences at all comparisons. However, the PMs showed a toward of higher risk of hepatotoxicity than NMs in all studies (RR: $1.60,95 \%$ CI: $\left.0.94^{\sim} 2.74, I^{2}=27 \%, \mathrm{p}=0.08\right)^{20-23,34-36}$. Sensitivity analysis showed the results did not alter significantly in all comparisons, but, the result of the comparison between PMs and NMs (RR: 2.38, 95\%CI: $\left.1.25^{\sim} 4.52, I^{2}=0 \%, \mathrm{p}=0.008\right)$ became statistically significant after excluding study by Kim et $a l^{35}$.

Subgroup analysis revealed that the results were not significantly changed in all subgroups. (Table 5)

\subsection{Neurotoxicity}

Four studies investigated the association of CYP2C19 phenotype with the safety outcome of neurotoxicity $21,23,24,35$ and meta-analysis results were shown in Table 6 . Our meta-analysis exhibited no statistically significant differences for all comparisons in all studies and all subgroups. Sensitivity analysis showed the results were not altered essentially.

Subgroup analysis revealed that the results were not significantly changed in all subgroups. (Table 6) 


\subsection{Publication bias}

Given the limited number of studies, we only performed publication bias at the comparison between IMs and PMs for safety outcome of overall adverse events (11 studies). No evidence of publication bias was observed by Begg's test $(\mathrm{p}=1.8805)$ and Egger's test $(\mathrm{p}=0.2510)$.

\section{Discussion}

Our update meta-analysis included a total of 20 studies of different countries. The meta-analysis suggested that the success rate and overall adverse events were strongly influenced by CYP2C19 polymorphisms. There was no significant association between CYP2C19 polymorphisms and hepatotoxicity or neurotoxicity. The meta-analysis showed that IMs and PMs were at a significant higher success rate in comparison with NMs. PMs were significantly associated with an increased incidence of all adverse events compared with NMs and IMs. In addition, PMs were more likely to experience hepatotoxicity than NMs, although there were no statistically significant differences.

Our findings reinforced a significant association between the CYP2C19 polymorphism and success rate of voriconazole. We found that PMs had a higher success rate than NMs, which was consistent with a previous meta-analysis by Li et al published in 2016 ( $\mathrm{n}=4$ studies, RR: $1.31,95 \% \mathrm{CI}: 1.04^{\sim} 1.67, I^{2}=0 \%, \mathrm{p}=0.02$ ) 15. Notably, the result of our meta-analysis indicated that IMs also had a higher success rate than NMs, which was in line with the higher voriconazole concentrations observed in PMs and IMs compared with $\mathrm{NMs}^{13}$. The above findings suggested that NMs might need to increase the standard dose of voriconazole. The magnitude of these results remained essentially unaltered in subgroups of the treatment and Asians. Owing to the scarce data, subgroups analysis could not be performed at subgroups of the prophylaxis and Caucasians.

PMs had a significant higher risk of the overall adverse events than NMs and IMs in the meta-analysis. Notably, when the analysis was stratified by ethnicity, the statistically significant difference disappeared in Caucasians. However, in subgroup of Asians, PMs remained at increased risk of the overall adverse events compared with NMs and IMs, suggesting that PMs might be relatively important for Asians and subsequently susceptible to adverse events while taking voriconazole. In addition, the significant difference remained in the subgroup of the treatment. Given the limited studies focusing on the subgroups of prophylaxis, the relationship of overall adverse events between PMs and NMs warrants further evaluation.

The meta-analysis suggested that there was no statistically significant association of the CYP2C19 phenotype with hepatotoxicity, which was in line with the results of a previous meta-analysis. Besides, the conclusion of several original researches did not support a link between the CYP2C19 phenotype status and hepatotoxicity 37-39. However, it should be noted that PMs showed a trend towards a higher risk of hepatotoxicity compared with NMs. In addition, when we excluded study by Kim et al ${ }^{35}$ in the process of sensitivity analysis, the result became statistically significant. This may be due to the current use of therapeutic drug monitoring (TDM) minimized their connection in this study. The lack of significance did not rule out the existence of a true causal relationship between hepatotoxicity and CYP2C19 phenotype status. More large trials are required to clarify the association.

There were no significant differences in association of CYP2C19 polymorphisms with neurotoxicity. The neurotoxicity such as hallucinations, headache, and dizziness are central nervous system disorders. Voriconazole is lipophilic, demonstrates a large volume of distribution $(4.61 \mathrm{~L} / \mathrm{kg})$ and is able to penetrate the blood-brain barrier. Lutsar et al ${ }^{40}$ reported that the median ratio of cerebrospinal fluid to plasma concentration of voriconazole was 0.46 in immunocompetent patients, and the voriconazole concentrations of brain/plasma ratios were $2^{\sim} 3$ in healthy adults ${ }^{41}$, which might have contributed to neurotoxicity. The lack of significance did not rule out the existence of a true causal relationship between neurotoxicity and CYP2C19 phenotype status. Apart from genetic polymorphisms, several other factors such as concomitant medications and patients' pathophysiological status might also contribute to clinical outcomes ${ }^{42,}{ }^{43}$. More large trials are required to clarify the association of CYP2C19 polymorphisms with neurotoxicity. 
To our knowledge, the meta-analysis assessing the association of CYP2C19 polymorphisms with efficacy and safety of voriconazole was the largest assessment to date. Our findings corroborated and extended the results of previous small meta-analysis. However, our meta-analysis had some limitations that should be mentioned. First, heterogeneity existed in criteria of treatment success, which means comparisons were indirect. Second, included studies varied in some aspects, such as comorbidities, infectious pathogen, site of infection, concomitant medicines and method of genotyping, which could be effect modifiers. Third, six studies located in Asia only detected alleles CYP2C19*2 and CYP2C19*3, and thus patients carrying CYP2C19*17 were classified to NMs who are assigned by default if CYP2C19*2, CYP2C19*3 and CYP2C19*17 are not detected. However, the frequency of CYP2C19*17 is present very low in Asian population $\left(0.15^{\sim} 0.44 \%\right)^{44}$. Clearly, studies including an adequate number of all four CYP2C19 alleles are needed to explore its relationship with the efficacy and safety of voriconazole.

\section{Conclusions}

In summary, the update meta-analysis supported CYP2C19 polymorphisms were related with clinical outcomes. Compared with NMs, IMs and PMs had significantly higher success rates. Additionally, PMs were significantly associated with an increased incidence of all adverse events compared with NMs and IMs. Therefore, there is a likelihood to guide personalized treatment with voriconazole based on CYP2C19 polymorphisms. Additionally, hepatotoxicity is a common adverse event in patients taking voriconazole and our study suggested that the relationship between hepatotoxicity and CYP2C19 polymorphisms deserves clinical attention. Researches are expected to further confirm these findings.

\section{References}

1 McCoy D, Depestel DD, Carver PL. Primary antifungal prophylaxis in adult hematopoietic stem cell transplant recipients: current therapeutic concepts.Pharmacotherapy 2009; 29 : 1306-25.

2 Eschenauer GA, Lam SW, Carver PL. Antifungal prophylaxis in liver transplant recipients.Liver Transpl $2009 ; 15: 842-58$.

3 Cordonnier C, Rovira M, Maertens J et al. Voriconazole for secondary prophylaxis of invasive fungal infections in allogeneic stem cell transplant recipients: results of the VOSIFI study. Haematologica 2010;95 : 1762-8.

4 Ko BS, Chen WT, Kung HCet al. 2016 guideline strategies for the use of antifungal agents in patients with hematological malignancies or hematopoietic stem cell transplantation recipients in Taiwan. Journal of microbiology, immunology, and infection = Wei mian yu gan ran za zhi 2018;51 : 287-301.

5 Marks DI, Pagliuca A, Kibbler CC et al. Voriconazole versus itraconazole for antifungal prophylaxis following allogeneic haematopoietic stem-cell transplantation. Br J Haematol 2011; 155 : 318-27.

6 Patterson TF, Thompson GR, Denning DW et al. Practice Guidelines for the Diagnosis and Management of Aspergillosis: 2016 Update by the Infectious Diseases Society of America. Clinical infectious diseases : an official publication of the Infectious Diseases Society of America 2016;63 :

7 Corzo-León DE, Perales-Martínez D, Martin-Onraet A, Rivera-Martínez N, Camacho-Ortiz A, VillanuevaLozano H. Monetary costs and hospital burden associated with the management of invasive fungal infections in Mexico: a multicenter study. Braz J Infect Dis 2018; 22 : 360-70.

8 Jin H, Wang T, Falcione BAet al. Trough concentration of voriconazole and its relationship with efficacy and safety: a systematic review and meta-analysis. The Journal of antimicrobial chemotherapy 2016; 71 : $1772-85$.

9 Luong M-L, Al-Dabbagh M, Groll AH et al. Utility of voriconazole therapeutic drug monitoring: a metaanalysis. The Journal of antimicrobial chemotherapy 2016; 71 : 1786-99.

10 Yanni SB, Annaert PP, Augustijns P, Ibrahim JG, Benjamin DK, Thakker DR. In vitro hepatic metabolism explains higher clearance of voriconazole in children versus adults: role of CYP2C19 and flavin-containing 
monooxygenase 3.Drug metabolism and disposition: the biological fate of chemicals 2010; 38 : 25-31.

11 Weiss J, Ten Hoevel MM, Burhenne J et al. CYP2C19 genotype is a major factor contributing to the highly variable pharmacokinetics of voriconazole. Journal of clinical pharmacology 2009; 49 : $196-204$.

12 Moriyama B, Obeng AO, Barbarino J et al. Clinical Pharmacogenetics Implementation Consortium (CPIC) Guidelines for CYP2C19 and Voriconazole Therapy.Clinical pharmacology and therapeutics 2017; 102 : 45-51.

13 Zhang Y, Hou K, Liu Fet al. The influence of CYP2C19 polymorphisms on voriconazole trough concentrations: Systematic review and meta-analysis.Mycoses 2021;

14 Trubiano JA, Crowe A, Worth LJ, Thursky KA, Slavin MA. Putting CYP2C19 genotyping to the test: Utility of pharmacogenomic evaluation in a voriconazole-treated haematology cohort. Journal of Antimicrobial Chemotherapy 2014;70 : 1161-5.

15 Li X, Yu C, Wang T, Chen K, Zhai S, Tang H. Effect of cytochrome P450 2C19 polymorphisms on the clinical outcomes of voriconazole: a systematic review and meta-analysis. European journal of clinical pharmacology 2016;72 : 1185-93.

16 Liberati A, Altman DG, Tetzlaff J et al. The PRISMA statement for reporting systematic reviews and meta-analyses of studies that evaluate health care interventions: explanation and elaboration. PLoS Med 2009;6 : e1000100.

17 Little J, Higgins JPT, Ioannidis JPA et al. Strengthening the reporting of genetic association studies (STREGA): an extension of the STROBE Statement.Hum Genet 2009; 125 : 131-51.

$18 \mathrm{Fu} \mathrm{S}$, Xiong X, Duan Jet al. Voriconazole plasma concentration monitoring in patients. Chin J Chin Pharmacol 2013; $29: 622-4$.

19 Wang T, Zhu H, Sun Jet al. Efficacy and safety of voriconazole and CYP2C19 polymorphism for optimised dosage regimens in patients with invasive fungal infections. International journal of antimicrobial agents2014; 44 : 436-42.

20 Wang T, Chen S, You H, Dong H, Wang X, Dong Y. Hepatotoxicity Study of Voriconazole Therapy in Patients with Invasive Fungal Infections. Chin Pharm J 2018;53 : 290-4.

21 Kim SH, Yim DS, Choi SMet al. Voriconazole-related severe adverse events: clinical application of therapeutic drug monitoring in Korean patients.International journal of infectious diseases : IJID : official publication of the International Society for Infectious Diseases 2011;15 : e753-8.

22 Wang Y, Wang T, Xie Jet al. Risk Factors for Voriconazole-Associated Hepatotoxicity in Patients in the Intensive Care Unit. Pharmacotherapy 2016;36 : 757-65.

23 Hicks JK, Quilitz RE, Komrokji RS et al. Prospective CYP2C19-Guided Voriconazole Prophylaxis in Patients With Neutropenic Acute Myeloid Leukemia Reduces the Incidence of Subtherapeutic Antifungal Plasma Concentrations. Clinical pharmacology and therapeutics 2020; 107 : 563-70.

24 Sienkiewicz B, Urbaniak-Kujda D, Dybko J et al. Influence of CYP2C19 Genotypes on the Occurrence of Adverse Drug Reactions of Voriconazole among Hematological Patients after Allo-HSCT. Pathology oncology research : POR 2018; 24 : 541-5.

25 Blanco-Dorado S, Maroñas O, Latorre-Pellicer A et al. Impact of CYP2C19 Genotype and Drug Interactions on Voriconazole Plasma Concentrations: A Spain Pharmacogenetic-Pharmacokinetic Prospective Multicenter Study. Pharmacotherapy 2020; 40 : 17-25.

26 Patel JN, Hamadeh IS, Robinson M et al. Evaluation of CYP2C19 Genotype-Guided Voriconazole Prophylaxis After Allogeneic Hematopoietic Cell Transplant.Clinical pharmacology and therapeutics $2020 ; \mathbf{1 0 7}$ : 571-9. 
27 Berge M, Guillemain R, Trégouet DA et al. Effect of cytochrome P450 2C19 genotype on voriconazole exposure in cystic fibrosis lung transplant patients. European journal of clinical pharmacology 2011; 67 : $253-60$.

28 Lee S, Kim BH, Nam WSet al. Effect of CYP2C19 polymorphism on the pharmacokinetics of voriconazole after single and multiple doses in healthy volunteers. Journal of clinical pharmacology 2012; 52 : 195-203.

29 Niu B, Wang G, Chen S, Weng Y. Evaluation of voriconazole guided by CYP2C19 gene polymorphism in the treatment of patients with invasive fungal infection. Journal of Capital Medical University 2018; 39 : 423-7.

30 Liang FH, Meng DM, Xie H, Xiao XL, Lv BJ, Chen WY. Effects of CYP2C19 gene polymorphisms on plasm concentration of voriconazole in critically ill patients with invasive fungal infection. Chin Hosp Pharm $J$ 2015; 35 : 1456-61.

31 Zuo Q, Xiao Q, Li J, Chen D, Liu J. Guiding effect of CYP2C19 gene polymorphism on drug therapy of patients with invasive fungal infection Chin J Nosocomiol 2020;30 : 25-8.

32 Li M, Zhou L, Zhang H, Guo Z, Qin F, Gao Y. The significance of CYP2C19 gene polymorphism in guiding voriconazole administration in patients with invasive fungal infection. Chin J Hosp Pharm 2020; 40 : 156-60,207.

33 Li Y, Zhang Y, Zhang L, Shi T, Fan H. The effect of CYP2C19 gene polymorphism on the blood concentration, efficacy and safety of voriconazole. Chin Hosp Pharm J 2019; 39 : 959-62.

34 Li Y, Zhang L, Feng X, Wang Y, Shen A, Liu S. Effect of CYP2C19 gene polymorphism on incidence of adverse drug reactions in Voriconazole. CHINA MEDICAL HERALD2019; 16 : 8-11.

35 Kim SH, Lee DG, Kwon JCet al. Clinical Impact of Cytochrome P450 2C19 Genotype on the Treatment of Invasive Aspergillosis under Routine Therapeutic Drug Monitoring of Voriconazole in a Korean Population. Infect Chemother 2013; 45 : 406-14.

36 Song Y, Jia MX, Yang Get al. Association of CYP2C19 and UGT1A4 polymorphisms with voriconazoleinduced liver injury. Personalized medicine 2019;17 : 15-22.

37 Levin M-D, den Hollander JG, van der Holt B et al. Hepatotoxicity of oral and intravenous voriconazole in relation to cytochrome P450 polymorphisms. The Journal of antimicrobial chemotherapy 2007; 60 : 1104-7.

38 Matsumoto K, Ikawa K, Abematsu K et al. Correlation between voriconazole trough plasma concentration and hepatotoxicity in patients with different CYP2C19 genotypes. International journal of antimicrobial agents 2009;34: 91-4.

39 Yamada T, Mino Y, Naito T, Kawakami J. Impact of flavin-containing monooxygenase 3 and CYP2C19 genotypes on plasma disposition and adverse effects of voriconazole administered orally in immunocompromised patients. Journal of infection and chemotherapy : official journal of the Japan Society of Chemotherapy 2019; 25 : 1019-25.

40 Lutsar I, Roffey S, Troke P. Voriconazole concentrations in the cerebrospinal fluid and brain tissue of guinea pigs and immunocompromised patients. Clinical infectious diseases : an official publication of the Infectious Diseases Society of America 2003; 37 : 728-32.

41 Henry ME, Bolo NR, Zuo CSet al. Quantification of brain voriconazole levels in healthy adults using fluorine magnetic resonance spectroscopy.Antimicrobial agents and chemotherapy 2013; 57 : 5271-6.

42 Alvarez-Lerma F, Allepuz-Palau A, Garcia MP et al. Impact of intravenous administration of voriconazole in critically ill patients with impaired renal function. Journal of chemotherapy (Florence, Italy) 2008;20 : 93-100. 
43 Zhong X, Tong X, Ju Y, Du X, Li Y. Interpersonal Factors in the Pharmacokinetics and Pharmacodynamics of Voriconazole: Are CYP2C19 Genotypes Enough for Us to Make a Clinical Decision? Current drug metabolism 2018;19 : 1152-8.

44 Hirota T, Eguchi S, Ieiri I. Impact of genetic polymorphisms in CYP2C9 and CYP2C19 on the pharmacokinetics of clinically used drugs. Drug metabolism and pharmacokinetics 2013; 28 : 28-37.

Table 1 Characteristics of included studies

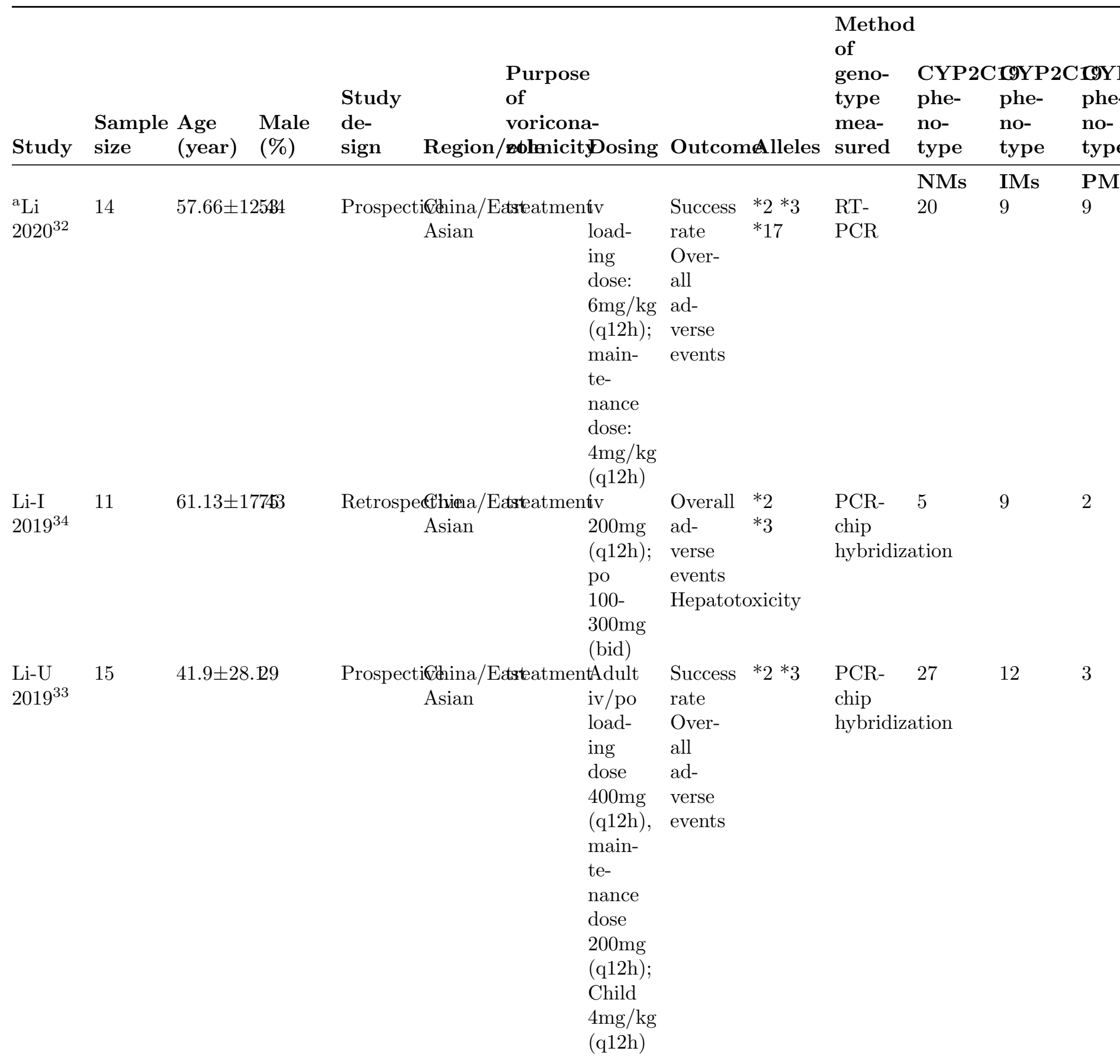




\begin{tabular}{|c|c|c|c|c|c|c|c|c|c|c|c|}
\hline Study & $\begin{array}{l}\text { Sample } \\
\text { size }\end{array}$ & $\begin{array}{l}\text { Age } \\
\text { (year) }\end{array}$ & $\begin{array}{l}\text { Male } \\
(\%)\end{array}$ & $\begin{array}{l}\text { Study } \\
\text { de- } \\
\text { sign }\end{array}$ & Region & $\begin{array}{l}\text { Purpose } \\
\text { of } \\
\text { voricona- } \\
\text { / ablenicitĐosing }\end{array}$ & OutcomAlleles & $\begin{array}{l}\text { Metho } \\
\text { of } \\
\text { geno- } \\
\text { type } \\
\text { mea- } \\
\text { sured }\end{array}$ & $\begin{array}{l}\text { CYP2 } \\
\text { phe- } \\
\text { no- } \\
\text { type }\end{array}$ & $\begin{array}{l}\text { TYYP2 } \\
\text { phe- } \\
\text { no- } \\
\text { type }\end{array}$ & $\begin{array}{l}\text { tgY] } \\
\text { phe- } \\
\text { no- } \\
\text { type }\end{array}$ \\
\hline $\begin{array}{l}\text { Wang } \\
2018^{20}\end{array}$ & 141 & $60 \pm 20$ & 67 & Retrosp & $\begin{array}{l}\text { Asian } \\
\text { Actima/1 }\end{array}$ & $\begin{array}{l}\text { Edsteatmentaccording } \\
\text { to } \\
\text { pack- } \\
\text { age } \\
\text { insert }\end{array}$ & $\begin{array}{l}\text { gHepatoto* } 2 \text { city } \\
{ }^{*} 3 \\
{ }^{*} 17\end{array}$ & NR & 62 & 62 & 17 \\
\hline $\begin{array}{l}\text { Sienkiew } \\
2018^{24}\end{array}$ & & $52($ medi & a68 & Prospec & tiReland/ & $\begin{array}{l}\text { Eppoupleyahaxiscording } \\
\qquad \begin{array}{l}\text { to } \\
\text { pack- } \\
\text { age } \\
\text { insert }\end{array}\end{array}$ & $\begin{array}{l}\text { gNeurotoxicity } \\
\text { Hepatotoxitity }\end{array}$ & $\begin{array}{l}\text { PCR- } \\
\text { RFLP }\end{array}$ & 4 & 15 & / \\
\hline $\begin{array}{l}\text { Song } \\
2019^{36}\end{array}$ & 25 & $\begin{array}{l}57.04 \pm 1 \\
50.30+- \\
19.45(\mathrm{D} \\
\text { case })\end{array}$ & $\begin{array}{l}8686 \text { (cor } \\
\text { LI }\end{array}$ & rBlyospec & $\begin{array}{l}\text { tiGhina/I } \\
\text { Asian }\end{array}$ & 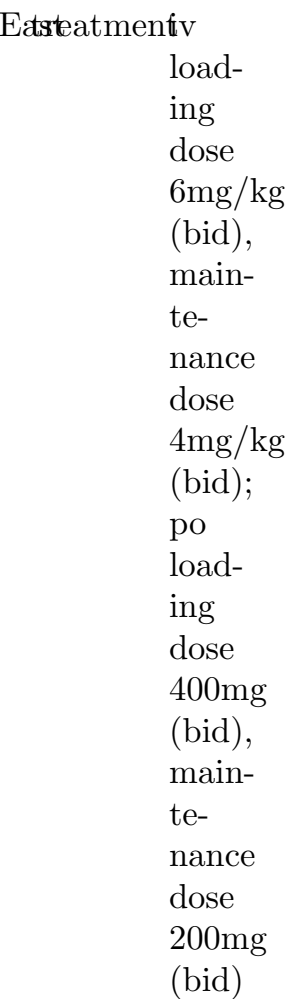 & Hepatotoxerity & $\begin{array}{l}\text { gene } \\
\text { chip } \\
\text { hybrid }\end{array}$ & 13 & 21 & 4 \\
\hline $\begin{array}{l}\text { Wang } \\
2016^{22}\end{array}$ & 63 & $56-85$ & 70 & Prospec & $\begin{array}{l}\text { Asiahina/I } \\
\text { Asian }\end{array}$ & 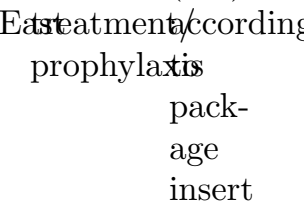 & $\begin{array}{l}\text { gHepatotox } 2 \text { cit:3 } \\
\text { *17 }\end{array}$ & $\begin{array}{l}\text { Sequen } \\
\text { MassAl }\end{array}$ & $\begin{array}{l}\text { ne: } 1 \\
\text { RAY }\end{array}$ & 24 & 8 \\
\hline
\end{tabular}




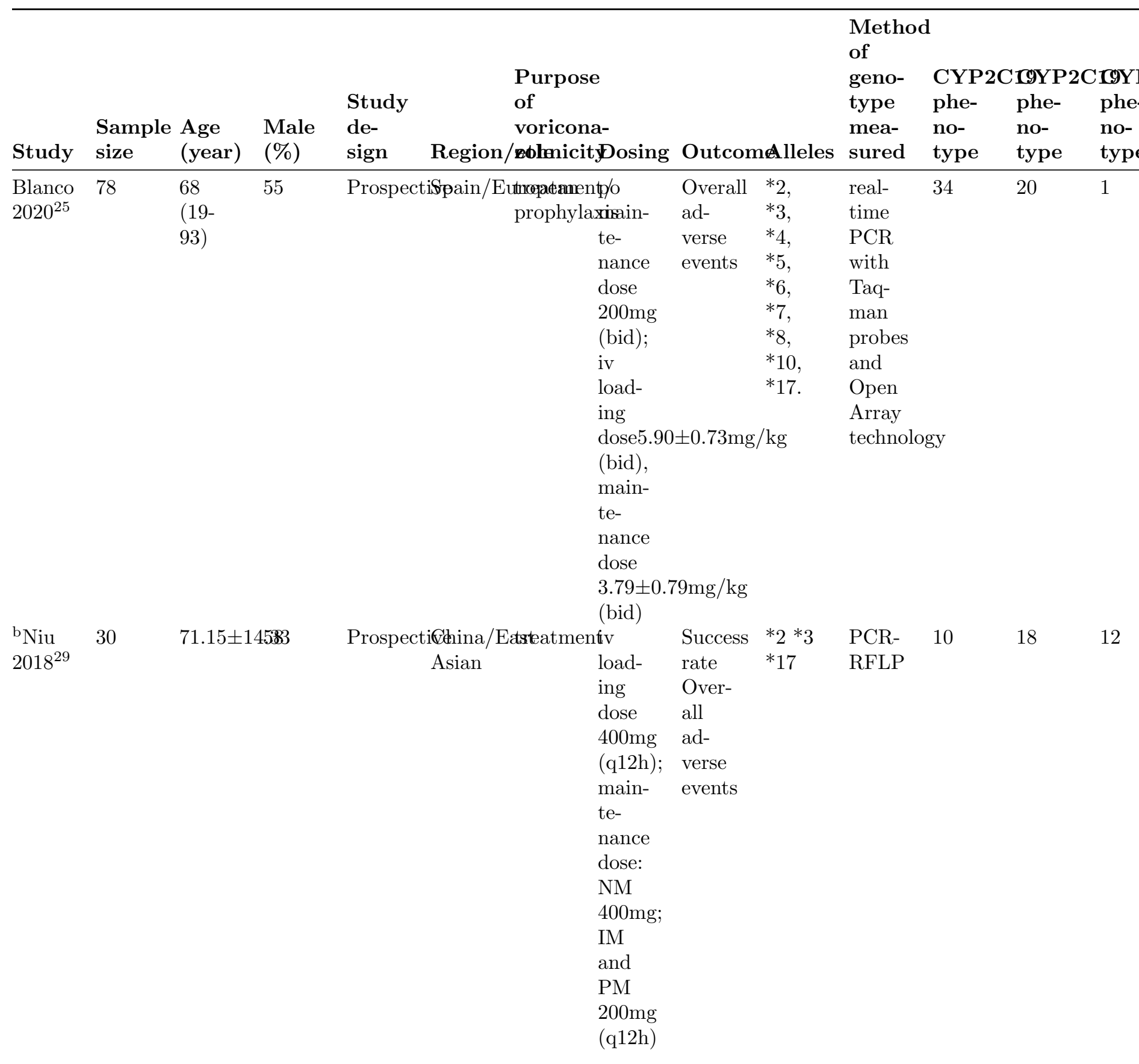




\begin{tabular}{|c|c|c|c|c|c|c|c|c|c|c|c|}
\hline \multirow{2}{*}{$\begin{array}{l}\text { Study } \\
{ }^{\mathrm{b}} \mathrm{Zuo} \\
2020^{31}\end{array}$} & $\begin{array}{l}\text { Sample } \\
\text { size }\end{array}$ & $\begin{array}{l}\begin{array}{l}\text { Age } \\
\text { (year) }\end{array} \\
\mathrm{NR}\end{array}$ & $\begin{array}{l}\begin{array}{l}\text { Male } \\
(\%)\end{array} \\
\mathrm{NR}\end{array}$ & $\begin{array}{l}\text { Study } \\
\text { de- } \\
\text { sign }\end{array}$ & $\begin{array}{l}\text { Purpose } \\
\text { of } \\
\text { voricona- } \\
\text { / ebhenicitĐosing }\end{array}$ & \multicolumn{2}{|c|}{ OutcomAlleles } & $\begin{array}{l}\text { Metho } \\
\text { of } \\
\text { geno- } \\
\text { type } \\
\text { mea- } \\
\text { sured }\end{array}$ & $\begin{array}{l}\text { CYP2 } \\
\text { phe- } \\
\text { no- } \\
\text { type }\end{array}$ & $\begin{array}{l}\text { TgYP2 } \\
\text { phe- } \\
\text { no- } \\
\text { type }\end{array}$ & $\begin{array}{l}\text { poY } \\
\text { phe } \\
\text { no- } \\
\text { typ }\end{array}$ \\
\hline & 78 & $\mathrm{NR}$ & $\mathrm{NR}$ & Prospe & $\begin{array}{l}\text { tiftuina/Edsteatmentv } \\
\text { Asian } \\
\text { load- } \\
\text { ing } \\
\text { dose } \\
\text { 400mg } \\
\text { (q12h); } \\
\text { main- } \\
\text { te- } \\
\text { nance } \\
\text { dose: } \\
\text { NM } \\
\text { 400mg; } \\
\text { IM } \\
\text { and } \\
\text { M200mg } \\
\text { (q12h) }\end{array}$ & $\begin{array}{l}\text { Overall } \\
\text { ad- } \\
\text { verse } \\
\text { events }\end{array}$ & $\begin{array}{l}* 2 \\
* 3 \\
* 17\end{array}$ & NA & 25 & 47 & 31 \\
\hline $\begin{array}{l}{ }^{\mathrm{b}} \text { Hicks } \\
2020^{23}\end{array}$ & 127 & $\begin{array}{l}64 \\
(19- \\
81)\end{array}$ & 52 & Prospe & $\begin{array}{ll}\text { America } & \text { NM, } \\
\text { AM, } & \text { IM, } \\
& \text { and } \\
& \text { PM } \\
& 200 \mathrm{mg} \\
& (\mathrm{q} 12 \mathrm{~h}) \\
& \mathrm{UM} \\
& 300 \mathrm{mg} \\
& (\mathrm{q} 12 \mathrm{~h})\end{array}$ & $\begin{array}{l}\text { Neuroto } \\
\text { Hepatot }\end{array}$ & $\begin{array}{l}x^{*} d \mathrm{ty} \\
\mathrm{o}^{*} \text { Bcity } \\
*^{*} 17\end{array}$ & $\begin{array}{l}\text { Lumine } \\
\text { xTAG } \\
\text { CYP2C } \\
\text { Kit } \\
\text { ver- } \\
\text { sion } \\
3\end{array}$ & $\begin{array}{l}\times 64 \\
19\end{array}$ & 56 & 7 \\
\hline $\begin{array}{l}{ }^{b} \text { Patel } \\
2020^{26}\end{array}$ & 50 & $54.0 \pm 1$ & 62 & Prospe & $\begin{array}{ll}\text { America } & \text { NM, } \\
\text { AM, Nonthophylaxis } \\
\text { IMd } \\
\text { and } \\
\text { PM } \\
200 \mathrm{mg} \\
(\mathrm{q} 12 \mathrm{~h}) \\
\text { UM } \\
300 \mathrm{mg} \\
(\mathrm{q} 12 \mathrm{~h})\end{array}$ & $\begin{array}{l}\text { Success } \\
\text { rate } \\
\text { Over- } \\
\text { all } \\
\text { ad- } \\
\text { verse } \\
\text { events }\end{array}$ & $\begin{array}{l}*_{2} *_{3} \\
*_{17}\end{array}$ & $\begin{array}{l}\text { TaqMa } \\
\text { Drug } \\
\text { Metabo } \\
\text { Geno- } \\
\text { typing } \\
\text { Assays }\end{array}$ & 24 & 23 & 3 \\
\hline
\end{tabular}




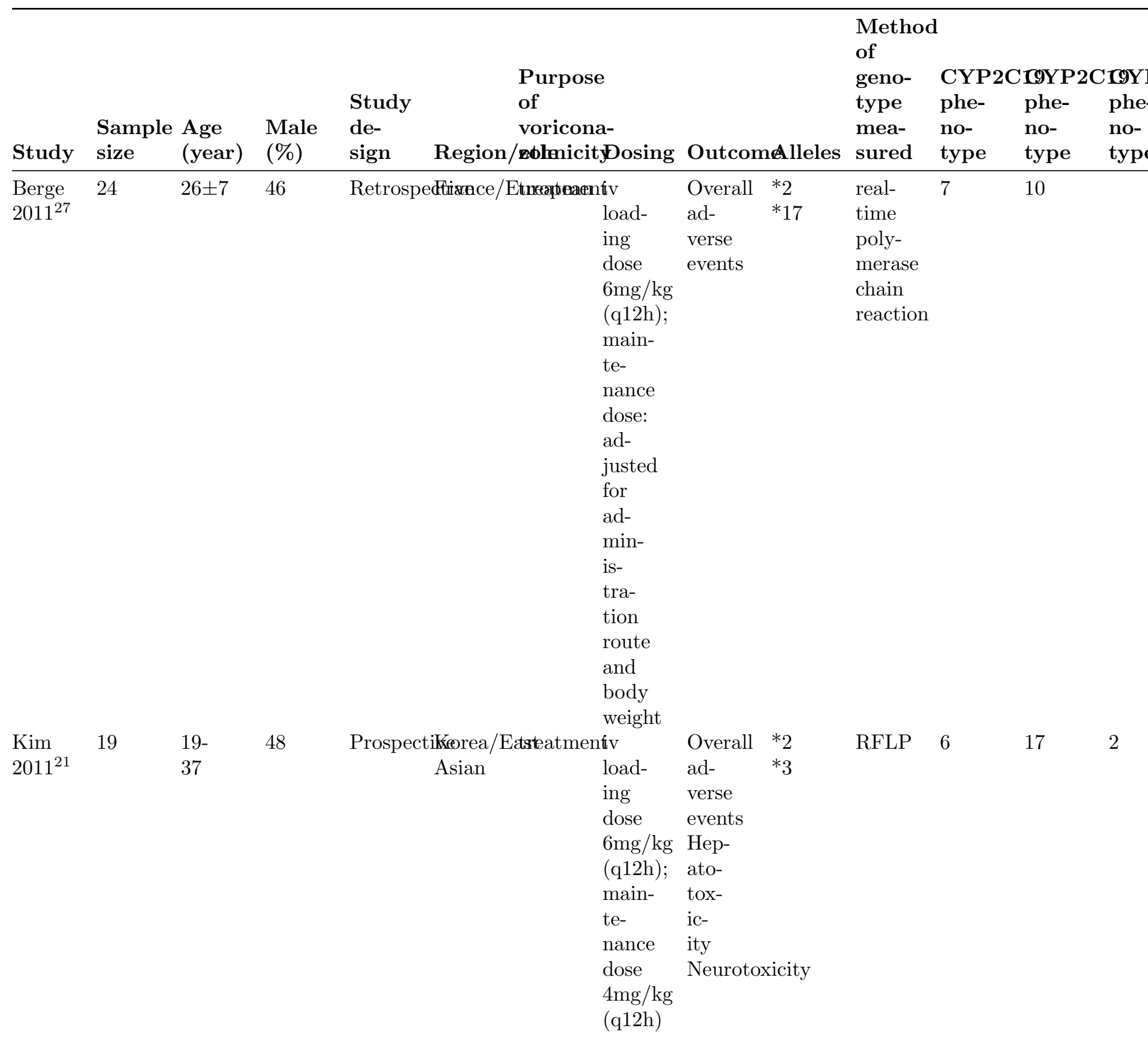




\begin{tabular}{|c|c|c|c|c|c|c|c|c|c|c|c|}
\hline \multirow{2}{*}{$\begin{array}{l}\text { Study } \\
{ }^{\mathrm{a}} \mathrm{Kim} \\
2013^{35}\end{array}$} & \multirow{2}{*}{$\begin{array}{l}\text { Sample } \\
\text { size }\end{array}$} & \multirow{2}{*}{$\begin{array}{l}\begin{array}{l}\text { Age } \\
\text { (year) }\end{array} \\
53 \pm 12\end{array}$} & \multirow{2}{*}{$\begin{array}{l}\begin{array}{l}\text { Male } \\
(\%)\end{array} \\
52\end{array}$} & \multicolumn{2}{|c|}{$\begin{array}{lr}\text { Study } & \text { of } \\
\text { de- } & \text { vo } \\
\text { sign } & \text { Region/Rol }\end{array}$} & \multicolumn{2}{|c|}{ OutcomAlleles } & $\begin{array}{l}\text { Metho } \\
\text { of } \\
\text { geno- } \\
\text { type } \\
\text { mea- } \\
\text { sured }\end{array}$ & $\begin{array}{l}\text { d } \\
\text { CYP2 } \\
\text { phe- } \\
\text { no- } \\
\text { type }\end{array}$ & $\begin{array}{l}\text { phYPo } \\
\text { phe- } \\
\text { no- } \\
\text { type }\end{array}$ & $\begin{array}{l}\text { coY } \\
\text { phe- } \\
\text { no- } \\
\text { type }\end{array}$ \\
\hline & & & & Prospec & $\begin{array}{l}\text { tikrerea/Edsteatmenfu } \\
\text { Asian } \\
\text { load- } \\
\text { ing } \\
\text { dose } \\
6 \mathrm{mg} / \mathrm{kg} \\
\text { (bid); } \\
\text { main- } \\
\text { te- } \\
\text { nance } \\
\text { dose } \\
\text { 4mg/kg } \\
\text { (bid) } \\
\text { or po } \\
\text { 200mg } \\
\text { (bid) }\end{array}$ & $\begin{array}{l}\text { Success } \\
\text { rate } \\
\text { Over- } \\
\text { all } \\
\text { ad- } \\
\text { verse } \\
\text { events } \\
\text { Hepa- } \\
\text { totox- } \\
\text { icity } \\
\text { Neuroto }\end{array}$ & $\begin{array}{l}{ }^{*} 2{ }^{*} 3 \\
{ }^{*} 17 \\
\text { xicity }\end{array}$ & $\begin{array}{l}\text { multiple } \\
\text { poly- } \\
\text { merase } \\
\text { chain } \\
\text { reaction }\end{array}$ & & 50 & 15 \\
\hline $\begin{array}{l}\text { Wang } \\
2014^{19}\end{array}$ & 144 & $60.6 \pm 13.5$ & .57 & Retrosp & $\begin{array}{ll}\text { eethima/Edsteatmentaccordin } \\
\text { Asian } & \text { to } \\
& \text { pack- } \\
& \text { age } \\
& \text { insert }\end{array}$ & $\begin{array}{l}\text { gSuccess } \\
\text { rate }\end{array}$ & $\begin{array}{l}* 2 \\
* 3 \\
* 17\end{array}$ & NR & 62 & 62 & 17 \\
\hline $\begin{array}{l}\text { Liang } \\
2015^{30}\end{array}$ & 42 & $60.2 \pm 14.9$ & .65 & Retrosp & $\begin{array}{l}\text { ecthica/Edsteatmentv } \\
\text { Asian } \\
\text { load- } \\
\text { ing } \\
\text { dose } \\
\text { 300mg } \\
\text { (q12h); } \\
\text { main- } \\
\text { te- } \\
\text { nance } \\
\text { dose } \\
\text { 200mg } \\
\text { (q12h) }\end{array}$ & $\begin{array}{l}\text { Success } \\
\text { rate } \\
\text { Over- } \\
\text { all } \\
\text { ad- } \\
\text { verse } \\
\text { events }\end{array}$ & $2 * 3$ & PCR & 7 & 30 & 12 \\
\hline $\begin{array}{l}\text { Trubiano } \\
2015^{14}\end{array}$ & & $\begin{array}{l}64 \\
\text { (median) }\end{array}$ & 63 & Prospec & 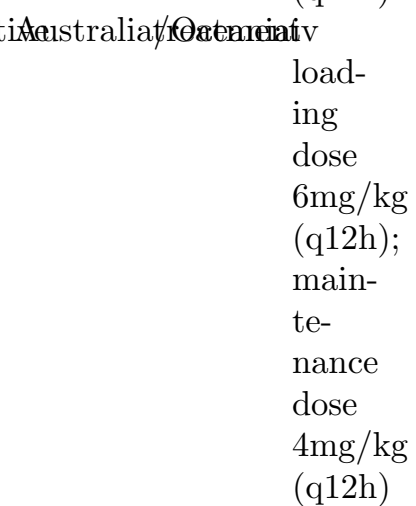 & $\begin{array}{l}\text { Overall } \\
\text { ad- } \\
\text { verse } \\
\text { events }\end{array}$ & $\begin{array}{l}* 1 \\
* 2 \\
* 3 \\
* 17\end{array}$ & $\begin{array}{l}\text { PCR } \\
\text { and } \\
\text { RFLP }\end{array}$ & 8 & 5 & / \\
\hline
\end{tabular}




\begin{tabular}{|c|c|c|c|c|c|c|c|c|c|c|c|c|}
\hline Study & $\begin{array}{l}\text { Sample } \\
\text { size }\end{array}$ & $\begin{array}{l}\text { Age } \\
\text { (year) }\end{array}$ & $\begin{array}{l}\text { Male } \\
(\%)\end{array}$ & $\begin{array}{l}\text { Study } \\
\text { de- } \\
\text { sign }\end{array}$ & $\begin{array}{r}\text { Purp } \\
\text { of } \\
\text { voric }\end{array}$ & $\begin{array}{l}\text { se } \\
\text { a- } \\
\text { itĐosing }\end{array}$ & Outcon & nAlleles & $\begin{array}{l}\text { Method } \\
\text { of } \\
\text { geno- } \\
\text { type } \\
\text { mea- } \\
\text { sured }\end{array}$ & $\begin{array}{l}\text { CYP2 } \\
\text { phe- } \\
\text { no- } \\
\text { type }\end{array}$ & $\begin{array}{l}\text { TOYP2 } \\
\text { phe- } \\
\text { no- } \\
\text { type }\end{array}$ & $\begin{array}{l}\text { 2CrgY } \\
\text { phe- } \\
\text { no- } \\
\text { type }\end{array}$ \\
\hline $\begin{array}{l}\text { Lee } \\
2012^{28}\end{array}$ & 18 & $20-50$ & 100 & Prospect & tikßorea/Astirial & $\begin{array}{l}200 \mathrm{mg} \\
\text { po bid }\end{array}$ & $\begin{array}{l}\text { Overall } \\
\text { ad- } \\
\text { verse } \\
\text { events }\end{array}$ & $\begin{array}{l}* 2 * 3 \\
* 17\end{array}$ & $\begin{array}{l}\text { TaqMan } \\
\text { allelic } \\
\text { dis- } \\
\text { crimi- } \\
\text { nation } \\
\text { assays }\end{array}$ & 6 & 6 & 6 \\
\hline $\begin{array}{l}\mathrm{Fu} \\
2013^{18}\end{array}$ & 10 & $22-83$ & 67 & Prospect & $\begin{array}{l}\text { tiGthina/Etateat } \\
\text { Asian prop }\end{array}$ & $\begin{array}{l}\text { ne2,00- } \\
\text { axtie0mg }\end{array}$ & $\begin{array}{l}\text { Success } \\
\text { rate }\end{array}$ & $*_{2} *_{3}$ & $\mathrm{NR}$ & 2 & 7 & 3 \\
\hline
\end{tabular}

NMs: normal metabolizers (CYP2C19*1/*1); IMs: intermediate metabolizers (CYP2C19*1/*2, CYP2C19*1/*3, CYP2C19*2/*17); PMs: poor metabolizers (CYP2C19*2/*2, CYP2C19*3/*3, CYP2C19*2/*3); UMs: ultra-rapid metabolizers (CYP2C19*1/*17, CYP2C19*17/*17); NR: not reported; NA: not available; "/" means no data.

a: in this study, patient with CYP2C19*1/*1, CYP2C19*1/*17 genotype was assigned as NMs groups.

b: the initial dosage regimen was different between CYP2C19 phenotype status.

Table 2 Genetic quality assessment of included studies

\begin{tabular}{llll}
\hline study & Clear statement of objectives and hypothesis & Clear eligibility criteria for study participants & Clear \\
\hline Li $2020^{32}$ & + & + & + \\
Li-I $2019^{34}$ & + & - & + \\
Li-U $2019^{33}$ & + & + & + \\
Wang $2018^{20}$ & + & + & + \\
Sienkiewicz $2018^{24}$ & + & - & + \\
Song $2019^{36}$ & + & + & + \\
Wang $2016^{22}$ & + & + & + \\
Blanco $2020^{25}$ & + & + & + \\
Niu $2018^{29}$ & + & + & + \\
Zuo $2020^{31}$ & + & + & + \\
Hicks $2020^{23}$ & + & + & + \\
Patel $2020^{26}$ & + & + & + \\
Berge $2011^{27}$ & + & + & + \\
Kim $2011^{21}$ & + & + & + \\
Kim $2013^{35}$ & + & + & + \\
Wang $2014^{19}$ & + & + & + \\
Liang $2015^{30}$ & + & + & + \\
Trubiano $2015^{14}$ & + & + & + \\
Lee $2012^{28}$ & + & + & + \\
Fu $2013^{18}$ & + & + & + \\
\hline
\end{tabular}

"+" detailed description, "-" no description

Table 3 Results of meta-analysis of success rate 
Table 3 Results of meta-analysis of success rate

\begin{tabular}{|c|c|c|c|c|c|}
\hline Success rate & Success rate & Success rate & Comparison & IMs vs NMs & PMs vs NMs \\
\hline \multirow[t]{5}{*}{ All } & \multirow[t]{5}{*}{ All } & \multirow[t]{5}{*}{ All } & $\mathrm{n}$ & 7 & 7 \\
\hline & & & $\mathrm{RR}(95 \% \mathrm{CI})$ & $1.18[1.03,1.34]$ & $1.28[1.06,1.54]$ \\
\hline & & & Heterogeneity $\left(\mathrm{I}^{2}\right)$ & 0 & 0 \\
\hline & & & $\mathrm{Z} \operatorname{tests}(\mathrm{P})$ & 0.02 & 0.01 \\
\hline & & & Refs. & $18,19,26,30,32,33,35$ & $18,19,26,30,32,33$ \\
\hline \multirow[t]{14}{*}{ Subgroups } & \multirow[t]{7}{*}{ Purpose of voriconazole } & \multirow[t]{5}{*}{ Treatment } & $\mathrm{n}$ & 5 & 5 \\
\hline & & & $\mathrm{RR}(95 \% \mathrm{CI})$ & $1.18[1.02,1.38]$ & $1.35[1.11,1.65]$ \\
\hline & & & Heterogeneity $\left(\mathrm{I}^{2}\right)$ & 0 & 0 \\
\hline & & & $\mathrm{Z} \operatorname{tests}(\mathrm{P})$ & 0.03 & 0.003 \\
\hline & & & Refs. & $19,30,32,33,35$ & $19,30,32,33,35$ \\
\hline & & \multirow[t]{2}{*}{ Prophylaxis } & $\mathrm{n}$ & 1 & 1 \\
\hline & & & Refs. & 26 & 26 \\
\hline & \multirow[t]{7}{*}{ Ethnicity } & \multirow[t]{5}{*}{ Asians } & $\mathrm{n}$ & 6 & 6 \\
\hline & & & $\mathrm{RR}(95 \% \mathrm{CI})$ & $1.18[1.02,1.36]$ & $1.31[1.08,1.59]$ \\
\hline & & & Heterogeneity $\left(\mathrm{I}^{2}\right)$ & 0 & 0 \\
\hline & & & $\mathrm{Z}$ tests $(\mathrm{P})$ & 0.03 & 0.006 \\
\hline & & & Refs. & $18,19,30,32,33,35$ & $18,19,30,32,33,35$ \\
\hline & & \multirow[t]{2}{*}{ Caucasians } & $\mathrm{n}$ & 1 & 1 \\
\hline & & & Refs. & 26 & 26 \\
\hline
\end{tabular}

NMs: normal metabolizers (CYP2C19*1/*1); IMs: intermediate metabolizers (CYP2C19*1/*2, CYP2C19*1/*3, CYP2C19*2/*17); PMs: poor metabolizers (CYP2C19*2/*2, CYP2C19*3/*3, CYP2C19*2/*3); UMs: ultra-rapid metabolizers (CYP2C19*1/*17, CYP2C19*17/*17); "/" means no data.

Table 4 Results of meta-analysis of overall adverse events

\begin{tabular}{|c|c|c|c|c|}
\hline Overall adverse events & Overall adverse events & Overall adverse events & comparison & IMs vs NMs \\
\hline \multirow[t]{5}{*}{ All } & \multirow[t]{5}{*}{ All } & \multirow[t]{5}{*}{ All } & $\mathrm{n}$ & 11 \\
\hline & & & $\mathrm{RR}(95 \% \mathrm{CI})$ & $1.22[0.87,1.73]$ \\
\hline & & & Heterogeneity $\left(\mathrm{I}^{2}\right)$ & 0 \\
\hline & & & $\mathrm{Z}$ tests $(\mathrm{P})$ & 0.25 \\
\hline & & & Refs. & $14,21,25,26,27,28,30,3$ \\
\hline \multirow[t]{15}{*}{ Subgroups } & \multirow[t]{7}{*}{ Purpose of voriconazole } & \multirow[t]{5}{*}{ Treatment } & $\mathrm{n}$ & 8 \\
\hline & & & $\mathrm{RR}(95 \% \mathrm{CI})$ & $1.24[0.85,1.80]$ \\
\hline & & & Heterogeneity $\left(\mathrm{I}^{\mathbf{2}}\right)$ & 0 \\
\hline & & & $\mathrm{Z}$ tests $(\mathrm{P})$ & 0.26 \\
\hline & & & Refs. & $14,21,27,30,32,33,34,3$ \\
\hline & & \multirow[t]{2}{*}{ Prophylaxis } & $\mathrm{n}$ & 1 \\
\hline & & & Refs. & 26 \\
\hline & \multirow[t]{8}{*}{ Ethnicity } & \multirow[t]{5}{*}{ Asians } & $\mathrm{n}$ & 7 \\
\hline & & & $\mathrm{RR}(95 \% \mathrm{CI})$ & $1.32[0.85,2.05]$ \\
\hline & & & Heterogeneity $\left(\mathrm{I}^{2}\right)$ & 0 \\
\hline & & & $\mathrm{Z}$ tests $(\mathrm{P})$ & 0.21 \\
\hline & & & Refs. & $21,28,30,32,33,34,35$ \\
\hline & & \multirow[t]{3}{*}{ Caucasians } & $\mathrm{n}$ & 4 \\
\hline & & & $\mathrm{RR}(95 \% \mathrm{CI})$ & $1.05[0.61,1.83]$ \\
\hline & & & Heterogeneity $\left(\mathrm{I}^{2}\right)$ & 0 \\
\hline
\end{tabular}




\begin{tabular}{|c|c|c|c|c|}
\hline Overall adverse events & Overall adverse events & Overall adverse events & comparison & IMs vs NMs \\
\hline & & & $\mathrm{Z}$ tests $(\mathrm{P})$ & 0.85 \\
\hline & & & Refs. & $14,25,26,27$ \\
\hline
\end{tabular}

NMs: normal metabolizers (CYP2C19*1/*1); IMs: intermediate metabolizers (CYP2C19*1/*2, CYP2C19*1/*3, CYP2C19*2/*17); PMs: poor metabolizers (CYP2C19*2/*2, CYP2C19*3/*3, CYP2C19*2/*3); UMs: ultra-rapid metabolizers (CYP2C19*1/*17, CYP2C19*17/*17); "/" means no data.

Table 5 Results of meta-analysis of hepatotoxicity

\begin{tabular}{|c|c|c|c|c|c|}
\hline Hepatotoxicity & Hepatotoxicity & Hepatotoxicity & Hepatotoxicity & comparison & IMs vs NMs \\
\hline All & All & All & All & $\begin{array}{l}\mathrm{n} \\
\mathrm{RR}(95 \% \mathrm{CI}) \\
\text { Heterogeneity }\left(\mathrm{I}^{\mathbf{2}}\right) \\
\mathrm{Z} \text { tests }(\mathrm{P}) \\
\text { Refs. }\end{array}$ & $\begin{array}{l}8 \\
1.19[0.80,1.77] \\
0 \\
0.4 \\
20,21,22,23,24,34\end{array}$ \\
\hline Subgroups & Purpose of voriconazole & Prophylaxis & $\begin{array}{l}\mathrm{n} \\
\mathrm{RR}(95 \% \mathrm{CI}) \\
\text { Heterogeneity }\left(\mathrm{I}^{2}\right) \\
\mathrm{Z} \text { tests }(\mathrm{P}) \\
\text { Refs. } \\
\mathrm{n} \\
\mathrm{RR}(95 \% \mathrm{CI}) \\
\text { Heterogeneity }\left(\mathrm{I}^{2}\right) \\
\text { Z tests }(\mathrm{P}) \\
\text { Refs. }\end{array}$ & $\begin{array}{l}\mathrm{n} \\
\mathrm{RR}(95 \% \mathrm{CI}) \\
\text { Heterogeneity }\left(\mathrm{I}^{2}\right) \\
\mathrm{Z} \text { tests }(\mathrm{P}) \\
\text { Refs. } \\
\mathrm{n} \\
\mathrm{RR}(95 \% \mathrm{CI}) \\
\text { Heterogeneity }\left(\mathrm{I}^{2}\right) \\
\mathrm{Z} \text { tests }(\mathrm{P}) \\
\text { Refs. }\end{array}$ & $\begin{array}{l}5 \\
1.27[0.79,2.02] \\
0 \\
0.32 \\
20,21,34,35,36 \\
2 \\
0.63[0.22,1.78] \\
0 \\
0.38 \\
23,24\end{array}$ \\
\hline & Ethnicity & Caucasians & $\begin{array}{l}\mathrm{n} \\
\mathrm{RR}(95 \% \mathrm{CI}) \\
\text { Heterogeneity }\left(\mathrm{I}^{2}\right) \\
\mathrm{Z} \text { tests }(\mathrm{P}) \\
\text { Refs. } \\
\mathrm{n} \\
\mathrm{RR}(95 \% \mathrm{CI}) \\
\text { Heterogeneity }\left(\mathrm{I}^{2}\right) \\
\mathrm{Z} \text { tests }(\mathrm{P}) \\
\text { Refs. }\end{array}$ & $\begin{array}{l}\mathrm{n} \\
\mathrm{RR}(95 \% \mathrm{CI}) \\
\text { Heterogeneity }\left(\mathrm{I}^{2}\right) \\
\mathrm{Z} \text { tests }(\mathrm{P}) \\
\text { Refs. } \\
\mathrm{n} \\
\mathrm{RR}(95 \% \mathrm{CI}) \\
\text { Heterogeneity }\left(\mathrm{I}^{2}\right) \\
\mathrm{Z} \text { tests }(\mathrm{P}) \\
\text { Refs. }\end{array}$ & $\begin{array}{l}6 \\
1.35[0.87,2.09] \\
0 \\
0.18 \\
20,21,22,34,35,36 \\
2 \\
0.63[0.22,1.78] \\
0 \\
0.38 \\
23,24\end{array}$ \\
\hline
\end{tabular}

NMs: normal metabolizers (CYP2C19*1/*1); IMs: intermediate metabolizers (CYP2C19*1/*2, CYP2C19*1/*3, CYP2C19*2/*17); PMs: poor metabolizers (CYP2C19*2/*2, CYP2C19*3/*3, CYP2C19*2/*3); UMs: ultra-rapid metabolizers (CYP2C19*1/*17, CYP2C19*17/*17); "/" means no data.

Table 6 Results of meta-analysis of neurotoxicity

\begin{tabular}{|c|c|c|c|c|c|c|}
\hline Neurotoxicity & Neurotoxicity & Neurotoxicity & comparisons & IMs vs NMs & PMs vs NMs & UMs v: \\
\hline \multirow[t]{5}{*}{ All } & All & All & $\mathrm{n}$ & 4 & 3 & 1 \\
\hline & & & $\mathrm{RR}(95 \% \mathrm{CI})$ & $0.67[0.34,1.34]$ & $1.28[0.39,4.20]$ & / \\
\hline & & & Heterogeneity $\left(\mathrm{I}^{2}\right)$ & 0 & 0 & / \\
\hline & & & $\mathrm{Z}$ tests $(\mathrm{P})$ & 0.26 & 0.68 & / \\
\hline & & & Refs. & $21,23,24,35$ & $21,23,35$ & 24 \\
\hline
\end{tabular}




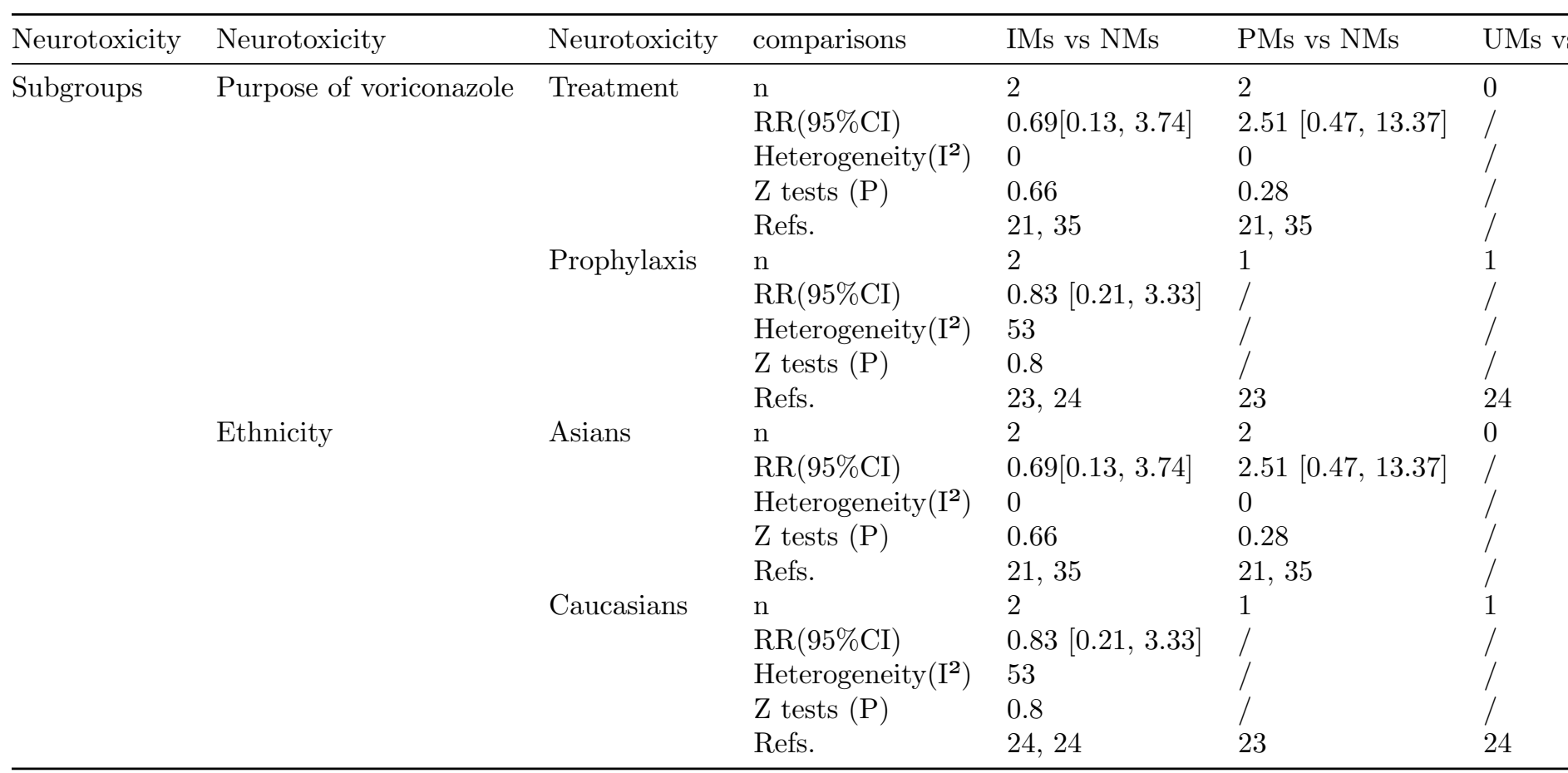

NMs: normal metabolizers (CYP2C19*1/*1); IMs: intermediate metabolizers (CYP2C19*1/*2, CYP2C19*1/*3, CYP2C19*2/*17); PMs: poor metabolizers (CYP2C19*2/*2, CYP2C19*3/*3, CYP2C19*2/*3); UMs: ultra-rapid metabolizers (CYP2C19*1/*17, CYP2C19*17/*17); "/" means no data.

Figure legends

Figure 1. Flow chart of eligible studies. 


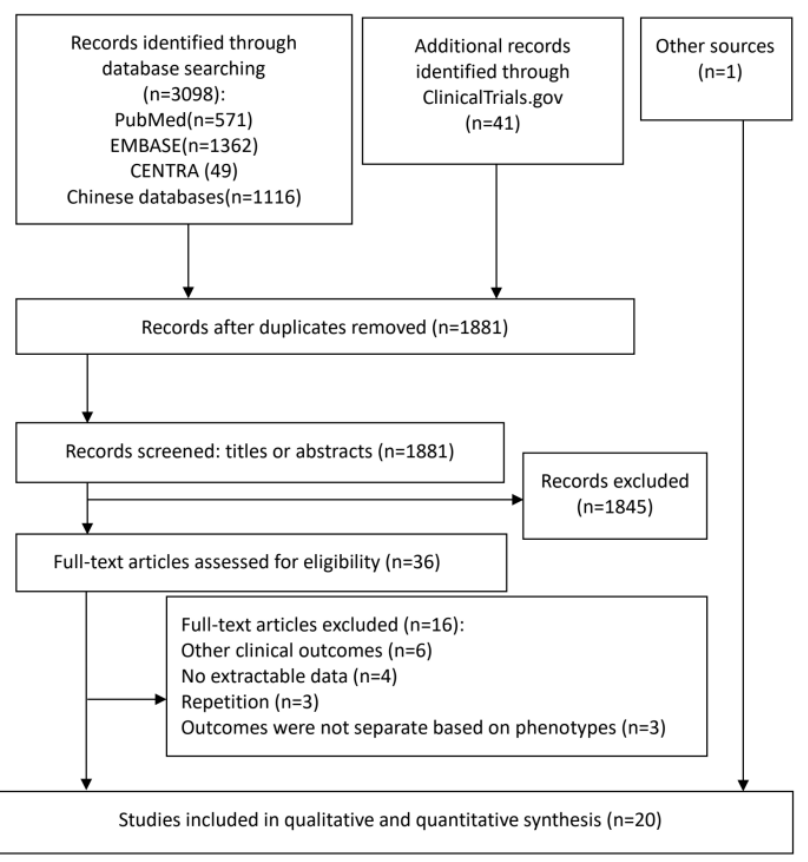

